\title{
Old and Young in Thucydides: Experience, Learning, and Themistocles
}

\author{
El viejo y el joven en Tucídides: \\ experiencia, aprendizaje y Temístocles
}

\author{
Antonis Tsakmakis ${ }^{1}$ \\ University of Cyprus (Chipre)
}

Recibido: 01-04-17

Aprobado: 15-04-17

\begin{abstract}
Thucydides composed his work in order to provide political education to his future readers. He wrote in a period which was fond of expert knowledge and appreciated intellectual progress. Knowledge-based education was available especially to young people. On the other hand, in his work he presents people learning from experience, a process which privileges people of a certain age. An exceptional figure is Themistocles who is characterized in a way which points to the limits of education and conveys an additional message to Thucydides' contemporaries.
\end{abstract}

Key-words: Education, Experience, Old Age, Alcibiades, Themistocles.

\section{Resumen}

Tucídides compuso su obra con el fin de proveer de educación política a sus futuros lectores. Escribió en un periodo afecto al conocimiento técnico y que valoraba el progreso intelectual. La educación basada en el conocimiento estaba disponible especialmente para la juventud. Por otro lado, en su obra presenta a los sujetos aprendiendo de la experiencia, un proceso que privilegia a gente de una cierta edad. Una figura de excepción

\footnotetext{
${ }^{1}$ (a.tsakmakis@ucy.ac.cy) Antonis Tsakmakis is Associate Professor of Greek at the University of Cyprus. His research interests include Greek historiography, Old comedy, the sophistic movement (Protagoras), Archaic poetry, Greek stylistics, Greek particles, the reception of antiquity in modern times, the teaching of Greek in secondary education. He is the author of Thukydides über die Vergangenheit (Tübingen, 1995) and co-editor of Brill's Companion to Thucydides, (Leyden-Boston, 2006) and Thucydides between History and Literature (Berlin-New York, 2013). Recently he has completed a new series of textbooks for teaching Greek in High School.
} 
es Temístocles, al que se representa en un modo que señala los límites de la educación y transmite un mensaje extra a los contemporáneos de Tucídides.

Palabras-clave: Palabras clave: Educación, experiencia, vejez, Alcibíades, Temístocles.

\section{Fathers and sons}

In his stimulating book Fathers and Sons in Athens, Barry Strauss argues that in the last decades of the $5^{\text {th }}$ century $\mathrm{BC}$ the theme of the father-son conflict is frequently found in dramatic and prose texts coming from Athens. For Strauss, the conflict was "well suited to be a central ideological symbol of the Athenian polis"2. It encoded more than the "universal and inevitable" (100) intergenerational tensions, and the physical opposition between old and new, inherent in every process of evolution: it became "a primary metaphor through which Athens constructed its experience of the political turmoil of the Peloponnesian War and its aftermath"3. But why was this decade "a period in which youthful and filial rebellion was very much on Athenians' minds, and in which a "generation gap" between young and old and fathers and sons was often noted"4? Strauss discerns three main reasons underlying the consciousness of a break with the old: the challenges of empire, the opportunities of democracy, and the training in rhetoric offered by sophists. Further on, the prominence of young men in public life after the death of Pericles (429 BC) may have been precipitated by demographic reasons (as a consequence of war and, especially, of the plague). At any rate, more than a reflection of historical reality, the preeminence of the motif indicates that "Athenians felt that their values had been challenged at the heart"'.

Strauss' analysis is valuable for the reconstruction of ideology in an epoch which is documented for us by an unprecedented number of surviving texts, nevertheless it needs a refinement which does justice to a factor which is usually underestimated in discussions about education in the period under discussion: the contents taught or discussed in the context of formal or informal instruction. Education was neither exclusively rhetorical nor "sophistic" in the sense of being constraint to argumentation techniques with the aim to undermine certainties or cast doubt on traditional beliefs. It also profited from the explosion of knowledge and information in various domains. Neither gymnastics of the

\footnotetext{
2 Strauss 1993: 14.

3 Falkner 1994.

4 Strauss 1993: 136.

Strauss 1993: 144.
} 
mind nor theory can develop in vacuo, without analogous contents. Part of the self-consciousness and the increasing self-esteem of the younger generation in the 420s may well have been a consequence of their broadened horizons and the amount of knowledge which gave them a privilege against elderly people. In a city which gathered intellectuals from all parts of the Greek world, at a period which saw considerable progress of expert knowledge in various areas $^{6}$, the ability to learn was valued differently than in earlier epochs, and the possession of knowledge could understandably generate feelings of superiority on the side of those who enjoyed this privilege ${ }^{7}$. Of course, access to education of this kind was neither massive nor systematic. Nevertheless, it irrevocably changed people's ideas about learning and challenged traditional perceptions of wisdom. We should not forget that the so-called sophists coined the notion of expert knowledge in the domain of politics, and taught that political virtue can be an object of instruction (P1., Prt. 320c-328b) ${ }^{8}$. The intensity of the father-son conflict may have been partly the result of a rapid progress in knowledge and theories about the world which changed the minds of the new generation in a way which resulted in the feeling that they were inhabiting an almost different world.

${ }^{6}$ This progress was documented in ambitious collections of all the available information, such as Hippias' encyclopedic works, Hellanicus' of Lesbos multiple writings on local history of various cities and other subjects, etc. In Aristophanes' Clouds, Socrates' studies range from meteorology and biology to the study of language, subjects that were treated in the treatises of various authors, such as Anaxagoras, Democritus, Protagoras, Prodicus etc. Most of the writings of this period have been lost, and much of what was taught or discussed has never been written. Xenophon's Memorabilia provides an example of the topics Socrates occasionally discussed with others, without having written anything (how to run the household or the state, how to be a good commander etc.), as well as of those he refused to cope with - but others did: meteorology, physics and the like. Herodotus' work is unique as an achievement of a single person, but it is also a telling example of the amount and the variety of knowledge that could be accessed separately by his contemporaries.

7 It is against this naïve optimism that Socrates' elenctic method of conversation was frequently directed. Xenophon's testimony confirms the fashion of pursuing expert knowledge among the youth: "These excellent beings he [sc. Socrates] recognised by their quickness to learn whatever subject they studied, ability to remember what they learned, and desire for every kind of knowledge on which depend good management of a household and estate and tactful dealing with men and the affairs of men. For education would make such beings not only happy in themselves, and successful in the management of their households, but capable of conferring happiness on their fellow-men and on states alike. His method of approach varied"; Xen., Mem. 4.2, translation Marchant).

${ }^{8}$ Euripides' plea for "good education" in the Suppliant Women is not necessarily a rhetorical dismissal of current education, but it acknowledges the existence of "good" and "less good" education. In the Funeral Oration of the play, Admetos focuses on the instruction of the new generation in virtue: "'every man who has practiced what is good is ashamed to become base. Courage is something that can be taught, since even a young child is taught to speak and be told things which he does not understand. And whatever things someone understands, he usually preserves them till old age. Since this is so, give children a good education" (913-917; translation Morwood). The association of $\pi \alpha\llcorner\delta \varepsilon i \alpha$ and courage is also found in Thucydides' Epitaphios (2.39.3). Strauss rightly remarks that many passages in Euripides' play stress the negative side of decisions influenced by the youth; but elderly people in this play also make a miserable performance. Strauss draws a rather unfavorable picture of the play's protagonist, Theseus. Yet, it should be noted that as a young ruler, he is at least able to learn and to make right decisions (cf. also Tsakmakis 2014). 


\section{Expert communities?}

The aim of this paper is to study the representation of age classes and how they relate to perceptions of learning in the first extant historical work written by an Athenian of this time: Thucydides' history of the Peloponnesian War (431-404 BC). Thucydides had experienced the rapid changes of mentality during the second half of the $5^{\text {th }}$ century, but he also had the advantage to write his work on the war(s) of Athens against Sparta, Corinth and Syracuse with knowledge of the outcome. He was the first historian to acknowledge the importance of rhetoric, as he included decades of speeches in his work, and was extremely sensible to all contemporary intellectual developments. He undoubtedly conceived his own work as "learning material" to be made available to an existing community of interested contemporaries who might profit from it, and use it to better serve their own communities. Mastering of rhetoric, acquaintance with Herodotus' huge synthesis of historical -and not only- information, his public service as a general, all this profiles him as an exceptional individual of his generation; but the characteristics which made him so exceptional may have been less rare in the ensuing generation.

The most telling example for the construction of what could be called a community of expert learning is Thucydides' introduction to the plague. Having stated that no expert knowledge could cope with the disastrous disease, the historian announces an exact description of its symptoms, limiting, however, expectations about its usefulness to the minimum: "Now any one, whether physician or layman, may, each according to his personal opinion, speak about its probable origin and state the causes which, in his view, were sufficient to have produced so great a departure from normal conditions; but I shall describe its actual course, explaining the symptoms, from the study of which a person should be best able, having knowledge of it beforehand, to recognize it if it should ever break out again" (2.48.3; translation Smith - all other translations of Thucydides are by Crawley). Even if the historian regards attempts by his contemporaries, specialists and non-specialists alike, to identify the causes of the malady as futile, we should not exaggerate the negative implications of his statement. The theories of others serve to Thucydides as a foil for his own contribution to the discussion, which undoubtedly elevates the standards of such an investigation'. By rejecting or supplementing them he confirms that he belongs to a community of people who interact with each other and pursue the truth. In equal terms, Thucydides expressed his vision about the use of his work: he composed it in the hope that it could prove useful to his readers

${ }^{9}$ In his own investigation of history, when it came to the causes of the Peloponnesian War, Thucydides was more confident about his ability to reveal them - and to criticize others (e.g. he names Hellanicus in 1.97.2) for their shortcomings. 
(1.22.4). The way his heroes treat learning in the work itself may be a first indication for his understanding of the educational value of his own writing.

\section{Old age in Greek literature before Thucydides}

It is a topos in all societies to associate old age with wisdom, and Greece does not make an exception. However, there is surprisingly little evidence about this idea in archaic sources ${ }^{10}$. Already the earliest choral poet, Alcman,

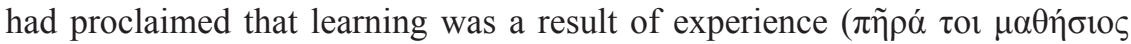
a $\rho \chi \alpha$; fr. 43 P), but the fragmentary state of the text does not allow to conclude whether it was associated with old age, nor is this idea explicitly articulated in the Iliad ${ }^{11}$. Nestor, the archetypical old advisor, had survived two generations of men (Il. 1.250-252), and it is from this long life that he draws examples which he recommends to his contemporaries as guidelines. However, he appeals neither to age nor even to experience per se as the source of his doctrines. His argument in favor of his authority is rather that Theseus and other heroes who were more important than his current audience had followed his advice (cf. Il. 1.259-270). He never states that all old men are wise, and the value of Nestor's opinion lies partly to the fact that he belongs to a generation which was superior to the present (Il. 7.124-160). His ability to advise others is ultimately a compensation for the lack of youthful vigor (Il. 4.318-325); on the other hand, he also concedes that younger people can speak prudently (Il. 9.53-59).

In the same vein, the image of the sage (e.g. the "Seven Sages") was not particularly associated with age. Contrarily, archaic lyric poetry and tragedy are full of negative illustrations of old age. Mimnermus deplores the suffering of aged people as a consequence of illness or of the decline of physical and mental power $^{12}$. Tragic choruses are usually unable to influence the course of events ${ }^{13}$. Although the command for respect towards aged people remained uncontested in Greek society, tragedy frequently puts this maxim under proof. In Sophocles those in power question the wisdom of the old, while Euripides lets elders behave in a manner which undermines de facto the principle of respectful treatment and invites opposite responses ${ }^{14}$.

10 The best treatment of the topic is Falkner 1995; cf. Gilleard 2007.

${ }^{11}$ It is closer to the world of the Odyssey, where Odysseus is supposed to have observed many cities and studied the mind of other people as a result of his adventures (Od. 1.1-4).

12 Social obligations towards the aged result from this condition; see Noussia-Fantuzzi 2010: 355-356.

13 See also Richardson 1933: 21 ("Aeschylus and Euripides place conservative views in the mouths of the aged choruses to combat the radical views of younger men").

${ }^{14}$ It is through suffering that one becomes wiser. Pind., Pyth. 2.25; Aesch., Ag. 176. In. Ol. 2.86-88 Pindar contrasts the knowledge of the wise by nature to that of "learners": "Wise is he who knows many things by nature, whereas learners who are boisterous and long-winded are like a pair of crows that cry in vain against the divine bird of Zeus" (translation Race). Learning rather implies a previous inability to overview a truth, and it costs some suffering to overcome this state of ignorance. 
In this context learning is frequently the non-intended outcome of a negative experience. Solon's fr. $27 \mathrm{~W}$ is a clear exception to this pessimism. The poet states that a man reaches mental maturity and is excellent in virtue and speech in the sixth, seventh and eighth "hebdomad" of his life, while the decline in the ninth is only slight. In alignment with this viewpoint, he confirms in fr. $28 \mathrm{~W}$ that he continues learning ("being instructed") while getting older. This dynamic approach to learning can be interpreted in various ways; at any rate, it entails the view that one is always in need of learning more - wisdom is not an inherited set of knowledge to be completely mastered by anyone.

Solon's approach to learning as a continuous process is more or less characteristic of the Ionian worldview, and also for the spirit which marked the transition from archaic to classic. Protagoras also incorporated the parameter of time into his teaching: in his opinion, knowledge of the Gods is constraint by the limited lifespan of a human bios (F 4) while he promises that the progress of his pupils will be in analogy with the time they spend with him (Pl., Prt. 318a). In Herodotus, age does not guarantee good decisions, at least for men in power ${ }^{15}$. Artabanus, whose performance is typical for a wise advisor, appeals to his age and experience in order to justify his skepticism towards Xerxes' plans to invade Greece, but he finally yields to the incitement conveyed by deceptive dreams (7.18.2-3). On her part, Atossa, advised her husband Darius to make war, while he is still young: "Now is your time for achieving great deeds, while you are still young: for as a man's mind grows with his body's growth, so as the body ages the mind too grows older and duller for all uses" (3.134.3; translation Godley). Both Atossa and Artabanus eventually drive their addressees to a disaster. Their ill advice is not only due to natural inferiority (as a woman and an old man, respectively); they both belong to the oriental world, and therefore lack Solon's enlightened insight into the truth, namely that even God can cause evil (the divine is $\tau \alpha \rho \alpha \chi \tilde{\omega} \delta \varepsilon \varsigma$ and $\varphi \theta 0 v \varepsilon \rho o ́ v$ - is loves upheaval and behave in a way which humans interpret as being full of envy) and is subject to Fate - the message of the story of King Croesus of Lydia in book I, which is emblematic for Herodotus' philosophy of history. Thus, Artabanus cannot realize divine deception, while Atossa is trapped in her ambition for Darius which ignores altogether the measures set by God.

\footnotetext{
${ }^{15}$ In Herodotus reference to age are usually related to the identification of children according to their relative age (Hdt. 2.55.3; 3.39.2; 3.50.3; 4.5; 5.104.1; 6.103.4; 7.205.1; 8.137-8). The terms for young and old are also used for cults (Hdt. 2.145.1), peoples (Hdt. 4.5.1), or to distinguish military classes (e.g. Hdt. 1.128.2; cf. also Thuc. 5.72.3-4; 5.75).
} 


\section{Youth vs. experience in Thucydides}

In Thucydides, the distinction between younger and older is almost always made in order to underline the different attitudes of the two age groups among citizens towards war. References to the young as a group are made in key passages of the narrative, while Greece was heading towards military collision. In both cases it is younger people who are affected by the frenzy of desire for war. First in 431: "And if both sides nourished the boldest hopes and put forth their utmost strength for the war, this was only natural. Zeal is always at its height at the commencement of an undertaking; and on this particular occasion the Peloponnesus and Athens were both full of young men whose inexperience made them eager to take up arms" (2.8.1); then, before the Sicilian Expedition: "Everyone fell in love with the enterprise. The older men thought that they would either subdue the places against which they were to sail, or at all events, with so large a force, meet with no disaster; those in the prime of life felt a longing for foreign sights and spectacles, and had no doubt that they should come safe home again; while the idea of the common people and the soldiery was to earn wages at the moment, and make conquests that would supply a never-ending fund of pay for the future" (6.24.3). Important are both the similarities and the differences between these two passages. At first sight, it is obvious that the behavior of the younger is driven by emotion rather than by reason, and this is due to their lack of experience ( $\alpha \pi \varepsilon i \rho i ́ \alpha)$. Nevertheless, the historian explicitly mentions that also elderly Athenians backed the decision for the Sicilian expedition, but on different grounds. The criteria these people took into consideration were the expected benefits, which would be worth the trouble, and the conditions that guaranteed a feeling of safety. Their reasoning seems to be nourished by their experience - their relative advantage against the younger. Thucydides probably regarded this stance as legitimate: in 2.65.11 he had remarked that the expedition "failed not so much through a miscalculation of the power of those against whom it was sent, as through a fault in the senders in not taking the best measures afterwards to assist those who had gone out". Thucydides' reference to the different motives of younger and older citizens for the Sicilian Expedition is supplemented by a further remark on the attitude of "common people". Apparently, these are people who are excluded from the groups who take active part in the deliberation with the least responsibility.

The speakers on both sides who in the two instances advise against war, Archidamus and Nicias, seem to be aware of the younger's fondness for military action; however, they try to oppose it in a different way each. Archidamus addresses the point in the opening of his speech in the Spartan assembly: "I have not lived so long, Spartans, without having had the experience of many wars, and I see those among you of the same age as myself, who will not fall 
into the common misfortune of longing for war from inexperience or from a belief in its advantage and its safety" $(1.80 .1)^{16}$. The Spartan king resorts to his experience as a prerequisite for a sound judgment on the available options; he also appeals to the experience of his age-mates as a distinct group within the community, who could back his considerations. His reference to advantage and safety addresses exactly the same points as in 6.24.3. This agreement suggests that, according to Thucydides, those who draw the right lessons from their experience of war had to primarily incorporate these two aspects in their calculations. On the contrary, the principal opponent of the Sicilian expedition, Nicias, opts for a personal attack on Alcibiades. He first tries to discard him because of his age: "And if there by any man here, overjoyed at being chosen to command, who urges you to make the expedition, merely for ends of his own -especially if he is still too young to command- who seeks to be admired for his stud of horses etc." (6.12.2). He then discards the younger citizens' capacity to decide: "that is a matter of importance, and not for a young man to decide or hastily to take in hand". This miserable strategy culminates in an appeal to the elderly: "When I see such persons now sitting here at the side of that same individual and summoned by him, alarm seizes me; and I, in my turn, summon any of the older men that may have such a person sitting next him, not to let himself be checked by shame, for fear of being thought a coward if he does not vote for war..." (6.13.1). Of course, no public speaker could have any chance in the Athenian -or any- assembly after having proclaimed that he excludes the most dynamic part of the audience from his addressees ${ }^{17}$. Thucydides' narrative does not confirm Nicias' accusations and Alcibiades will take the opportunity to cast on Nicias the responsibility for causing an internal strife between Athenian citizens $(6.18 .6)^{18}$.

In his first appearance in the work (5.43.2) Alcibiades had been introduced by Thucydides as "a man still young in years for any other Hellenic city, but distinguished by the splendor of his ancestry". There is no reason to read this comment on Alcibiades' age as criticism. Nor does Thucydides imply anywhere

\footnotetext{
${ }^{16}$ For Archidamus this idea becomes a standard element of his self-styling. It figures also at the beginning of his first address to his commanders at the Isthmus: "Peloponnesians and allies, our fathers made many campaigns both within and without the Peloponnesus, and the elder men among us here are not without experience in war. Yet we have never set out with a larger force than the present; and if our numbers and efficiency are remarkable, so also is the power of the state against which we march" (Thuc. 2.11.1). Given the importance of age classes in Sparta and the high esteem for elderly people in its society, it would be reasonable to assume that Thucydides reproduces here what he believed to be appropriate for the occasion, according to his perception of typical Spartan manners.

${ }_{17}$ Another speaker who attempts to segregate one age group among his audience is Athenagoras, who is openly condemned by Thucydides as a demagogue (Thuc. 6.38.5; cf. 6.39.2). He associates youth with oligarchic aspirations, later revolutionary action by young Athenian oligarchs will be described as violent; cf. Westlake 1968: 212-13 n. 2; Hornblower 2008: 378.

${ }^{18}$ It is in book 8 that age will be occasionally used again as a defining characteristic of people in Athens: 8.1.3; 8.65.2; 8.69.4; 8.92.6.
} 
that his youth influences his actions -apart of course from Nicias unproved allegations. Hornblower rightly remarks that "it is probably safe to say, despite the generalizing scope of $\dot{\varepsilon} v \alpha \not \lambda \lambda \eta\rceil$ ó $\lambda \varepsilon 1$, that the main comparison Th. has in mind is with the Spartans"19.

The different psychology of various age classes is normal, and a good commander has to take this reality into account. Archidamus included the psychology of the youth in his calculations about possible Athenian reactions to his campaign against Attica ${ }^{20}$, and he is confirmed in his expectations ${ }^{21}$, but Pericles manages to control his fellow citizens and carry out his own strategy till the end ${ }^{22}$. For the Athenian speakers in Sparta it is a sign of self-consciousness that they can differentiate between the various age groups in their audience ${ }^{23}$.

\section{The controversial use of experience and Themistocles' apeiria}

It is thus uncontestable that younger people have to learn from those who have lived longer. This is a truism that can be variously used by speakers: "weigh well these considerations, and let your youth learn what they are from their elders" (1.42.1) - the rhetorical effect of the Corinthians' appeal to the elders' experience is again to avoid war, independently from the questionable content of the facts they ask their audience to retrieve from their memory (the Corinthians' alleged services to the Athenians). Lack of experience, $\alpha \pi \varepsilon i p i ́ \alpha$, can lead to a wrong judgement about reality: "on the other hand, he who is stranger to the matter (á $\pi \varepsilon 1 \rho \circ \varsigma)$ may be led by envy to suspect exaggeration if he hears anything above his own nature (2.35.2). In this sentence of the Epitaphios Pericles introduces a further principle which, besides knowledge from experience, can lead to right judgment: man's consciousness of his own "nature" (

${ }^{19}$ Hornblower 2008: 101. Thucydides' judgement of Spartan (and Dorian) gerontocracy seem not to have been favorable. In the Pentecontaetia he makes special mention of a characteristic incident which, as he notes, led to a considerable disaster for Corinth, which is reported at unusual (for the standards of the Pentecontaetia) length: after an indecisive battle between Athenians and Corinthians, the Athenians had set up a trophy; "urged by the taunts of the elders in their city, the Corinthians made their preparations, and about twelve days afterwards came and set up their trophy as victors". They were, however, attacked by the Athenians and a considerable part of their forces was eliminated (Thuc. 1.105.6-106.2). For a similar blame addressed by an elderly man to the Spartan King Agis in Mantinea see 5.65.2: elders can influence even military decisions. For the Spartans' respect towards aged people see Xen., Mem. 3.15. Cf. David 1991.

20 "He hoped that the Athenians might possibly be tempted by the multitude of their youth and by their unprecedented preparedness for war to come out to battle and attempt to stop the devastation of their lands" (Thuc. 2.20.2).

21 Thuc. 2.21.2.

22 Thuc. 2.21.3.

23 "There was also a wish to call attention to the great power of Athens, and to refresh the memory of the old and enlighten the ignorance of the young..." (1.72.2). 
the historian, admits that people evaluate information about human behavior according to their standards of the "human"; this is the same principle which Thucydides applied in 1.22.4 to historical events in order to adequately assess

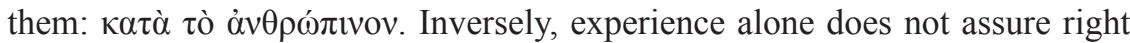
judgement. In his last direct battle exhortation, shortly before the final defeat in Sicily, Nicias tries to encourage his men through a syllogism which eventually privileges the irrational over the rational: "You must not lose your heart, or be like men without any experience, who fail in a first attempt, and ever afterwards fearfully expect a future as disastrous. But let the Athenians among you who have already had experience of many wars, and the allies who have joined us in so many expeditions, remember the surprises of war, and with the hope that fortune will not be always against us, prepare to fight again in a manner worthy of the number which you see yourselves to be" (Thuc. 7.61.2-3). According to Nicias, the message of experience is that chance is unpredictable, and, hence, it could spare them against every expectation! Nicias' statement is highly theoretical and it is not supported by any concrete evidence. The answer is provided by Pericles who denies the role played by chance in the growth of Athens: "and more by wisdom than by fortune, more by daring than by strength, they [sc. our fathers] beat off the barbarian and advance their affairs to their present height" (Thuc. 1.144.4) ${ }^{24}$.

There is one exception that proves the rule of the mechanics of experience: Themistocles. In his case, experience is explicitly denied as a source for his political insight. His inborn qualities made any form of external influence on his mental formation unnecessary: "By his own native capacity, which was

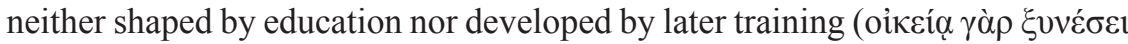

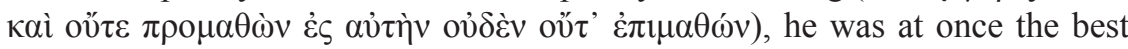
judge in those sudden crises which admit most distant possibilities. An able theoretical expositor of all that came within the sphere of his practice, he was not without the power of passing an adequate judgment in matters which he had

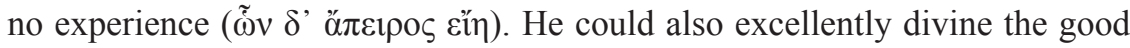
and evil which lay hidden in the unseen future" (Thuc. 1.138.3). The pointed antithesis between the participles $\pi \rho \circ \mu \alpha \omega \dot{\nu}$ and غ̇ं $\mu \alpha \theta \omega \dot{\nu}$ seems to emphasize the notion of learning and to suggest important implications for a current discussion about education (Protagoras in the platonic dialogue used in his myth the figures of Prometheus and Epimetheus with the aim to highlight the two types of learning). Themistocles' superb performance is neither the result of education received in advance, nor due to the lessons taught by experience.

Which is the message conveyed by this idealized image of a political forefather of Athenian growth? It does not deny the importance of learning, but at the same time it points to its limits. As education does not guarantee progress,

\footnotetext{
${ }^{24}$ On the problem of chance vs. intelligence see Edmunds 1975.
} 
similarly progress does not rely solely on education. Charismatic individuals will always be needed, and people will have to recognize them and use them: this is an additional lesson to be obtained from Thucydides' work.

Thucydides' History makes accumulated experience of an important period available to a community of readers. Thus, it transforms for them learning acquired afterwards, the author's lived experience over the years (which also includes failures, catastrophes and suffering not only of cities but also for individuals), to learning to be achieved in advance, through study. However, education, any form of education, cannot guarantee success in a deterministic way. For the city, the benefit from charismatic and integer leaders is also indispensable. They possess "the skill that copes with chaos - be it that of the Athenian Assembly or a battle" 25 .

${ }^{25}$ Shanske 2006: 63 . 


\section{Bibliography}

David 1991: E. David, Old age in Sparta (Amsterdam, 1991).

Edmunds 1975: L. Edmunds, Chance and Intelligence in Thucydides (Cambridge, Mass., 1975).

Falkner 1995: T.M. Falkner, The Poetics of Old Age in Greek Epic, Lyric, and Tragedy (Norman and London, 1995).

Falkner 1994: T.M. Falkner, Review Strauss 1993, "BMCRev", 94.06.05.

Gilleard 2007: C. Gilleard, Old Age in Ancient Greece: Narratives of desire, narratives of disgust, "Journal of Aging Studies", 21 (2007), pp. 81-92.

Hornblower 2008: S. Hornblower, A Commentary on Thucydides, III: Books 5.25-8.109 (Oxford, 2008).

Noussia-Fantuzzi 2010: M. Noussia-Fantuzzi, Solon the Athenian, the Poetic Fragments (Leiden-Boston, 2010).

Strauss 1993: B. Strauss, Fathers and Sons in Athens. Ideology and Society in the Era of the Peloponnesian War (London, 1993).

Richardson 1933: B.E. Richardson, Old Age among the Ancient Greeks. The Greek Portrayal of Old Age in Literature, Art, and Inscriptions (Baltimore, 1933).

Shanske 2006: D. Shanske, Thucydides and the Philosophical Origins of History (Cambridge, 2006).

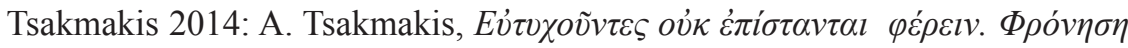

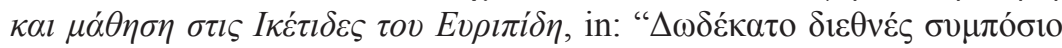

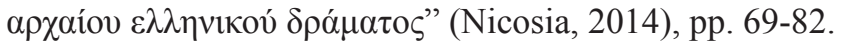

Westlake 1968: W.D. Westlake, Individuals in Thucydides (Cambridge, 1968). 